\title{
Actuarial Reserves, Provisions and Contingent Liabilities in DCF Valuation
}

\author{
Paweł Mielcarz, Dmytro Osiichuk, Paweł Wnuczak*
}

\begin{abstract}
The paper presents a practical guidance for the treatment of employee benefits, provisions, and contingent liabilities in the DCF valuation models. Market practitioners often encounter difficulties while incorporating the figures of actuarial reserves and provisions, which are themselves a result of a projection, into the cash flow calculation. Although the concepts of employee benefits, provisions and contingent liabilities are clearly defined in both Polish and international accounting standards, their accordance with the logic and assumptions of the DCF valuation model poses some technical problems, which are confronted in the paper. Among other things, we address the issues related to actuarial reserves, which are often neglected when outlining a company's capital structure and calculating the WACC. We propose a step-by-step algorithm allowing to transfer the accounting inputs into the DCF model, which may be of considerable interest to practicing valuators.
\end{abstract}

Keywords: actuarial reserves, provisions, contingent liabilities, DCF valuation

\section{Introduction}

Actuarial reserves, provisions and contingent liabilities have a common feature - they possess an inherent element of uncertainty. The risk embedded in the estimates of the accounting figures makes the task of valuation of the respective assets and liabilities particularly challenging. What makes the situation even more complicated is the lack of a generally known and adopted prescriptive methodology solving the problem of incorporating the actuarial reserves, provisions, and contingent liabilities into the DCF valuation models. Faced with the task of building a free cash flow projection, analysts often struggle with the difficulties related to the uncertainty surrounding the contingent liabilities and provisions. The problem stems from the lack of a precise algorithm which would allow the valuator to apportion the liabilities and provisions between the respective elements of the free cash flow calculation. Before proceeding with the value estimates, an analyst has to come up with a reliable projection of contingent liabilities and provisions which may be a daunting task. The Polish (KSR 6) and international accounting standards (IAS 19, 37) give detailed definitions

\footnotetext{
* dr Paweł Mielcarz, Akademia Leona Koźmińskiego w Warszawie, Katedra Finansów, e-mail: pmielcarz@alk.edu. pl, mgr Dmytro Osiichuk, Akademia Leona Koźmińskiego w Warszawie, Katedra Finansów, e-mail: dosiichuk@ alk.edu.pl, dr Paweł Wnuczak, Akademia Leona Koźmińskiego w Warszawie, Katedra Finansów, e-mail: pawelw@ alk.edu.pl.
} 
of the analysed concepts, however, their practical application in the process of DCF valuation requires a thorough clarification. Aware of the challenges encountered by the practicing valuators, we decided to come up with a detailed guidance elaborating on the treatment of the actuarial reserves, provisions and contingent liabilities through the entire process of company valuation.

The paper is organized in the following way: first, we set out the terminological background of the discussion in accordance with the international accounting standards (IAS 19, 37); then we address the problem of projection and valuation of provisions; afterwards, we present the approach to incorporating the actuarial reserves into the valuation accompanied with a numerical example based on a standard DCF model (Damodaran, 2010), which may serve as a foundation to work on for practitioners.

\section{The Accounting Treatment and Measurement of Actuarial Reserves, Provisions and Contingent Liabilities}

\subsection{Provisions}

Pursuant to the IAS 37 'Provisions, Contingent Liabilities and Contingent Assets', provision is defined as a 'liability of an uncertain timing or amount'. The uncertainty is the distinguishing feature making the provisions different from payables or accruals. Despite the inherent risk, provisions meet the criteria for recognition in financial statements: 1) a present obligation exists at the end of the reporting period; 2) and a reliable estimate of the potential outflow of resources necessary to settle the liability can be estimated. A Quantification of the provisions is based upon the notion of obligation classes (e.g. warranties or other types of similar contracts constitute obligation classes): the provision is recognized for the entire class based on the probability of outflow for the purpose of the settlement of an individual contract (IAS 37).

The lack of evidence regarding the dynamics of the provisions, reserves or liabilities in the future constitutes a considerable impediment to the process of free cash flow projection. For the purposes of DCF valuation we will base the prognoses on the historical dynamics of the estimated provisions. Following the instructions in IAS 37, we determine the range of possible outcomes (each entailing a different amount of obligation), assess their probability and estimate a sufficiently reliable amount of provision. At the same time, allowance should be made for the risk inherent in a projection and the possible future events, which may considerably alter the amount of the provision. The standard prompts to make the estimates of the provisions on a prudent basis in order to avoid a deliberate under- or overstatement of the liabilities.

The disclosure of the provisions includes the following information (for each class of provisions as per IAS 37): 1) the nature of the legal or constructive obligation and the expected timing of the outflows of assets embedding economic benefits; 2) the uncertainty 
inherent in the provision projection and the possible future events which may impact the amount of the provision, as well as the amounts of possible reimbursements. While preparing the free cash flow projection we will rely on the above disclosure requirements.

\subsection{Actuarial reserves}

Actuarial reserves and, in particular, the long-term and post-employment employee benefits constituting its major part, require special attention in the process of DCF valuation. The IAS 19 'Employee Benefits' states that an entity must recognize an expense when the benefit and the service rendered by an employee match in time (recognized as accruals in the financial statements and treated respectively in the DCF valuation), and a liability when the benefit for the currently rendered services is postponed to the future. We will be dealing with the post-employment (retirement benefits, life insurance, post-employment medical care etc.) and long-term benefits (long-service leave, jubilee and long-term disability benefits etc.). In case of a defined-contribution plan, the IAS 19 states that a contribution payable by an entity must be recognized as an accrued expense. Measurement of the liability in case of a defined-benefit plan is much more difficult and requires the application of the actuarial valuation based on a set of assumptions, as well as discounting techniques (Projected Unit Credit Method, IAS 19) conditioned by the long-term character of the liability. The next step, after determining the value of the obligation in the frame of the defined-benefit plan, is the apportionment of the present value of the benefits to the periods of service in accordance with the plan formula (IAS 19). For the purposes of this paper we will assume that the obligation has already been valued using the actuarial techniques. Instead, we will concentrate on the practical problem of incorporating the obtained figure into the DCF model and explaining its influence on the valuation outcomes.

\subsection{Contingent liabilities}

A contingent liability is a potential liability resulting from a legally enforceable or constructive obligation, whose existence hinges upon the occurrence or non-occurrence of a certain event of a probabilistic nature, which is not under control of the entity. Contingent liabilities are not recognized in the financial statements due to: 1) low probability of potential outflow of resources embodying economic benefits to settle the obligation; 2) lack of the possibility to measure the amount of the obligation with sufficient reliability (IAS 37). Therefore, the contingent liabilities are not directly included in the DCF valuation as long as the potential outflow and its probability cannot be estimated with a sufficient precision (afterwards, the contingent liability becomes a provision). However, an analysis of the disclosed contingent liabilities constitutes an important element of the company valuation. 


\section{Projection of Provisions}

IAS 37 requires the provision to be the best estimate of the amount necessary to settle the liability, i.e. the amount that the entity would rationally deem to be sufficient in order to settle or transfer the obligation. To arrive at the best estimate management must rely on personal judgment, market data and experts' opinion. The IAS 37 suggests using the expected value (obtained by evaluating the probabilities of the set of possible scenarios) as a benchmark for the provision estimate as it allows incorporating and quantifying the uncertainty in the obligation estimate. We will ignore the techniques of provision calculation and concentrate on the ways of incorporating them into the DCF valuation. The appropriate algorithm is presented in Figure 1.

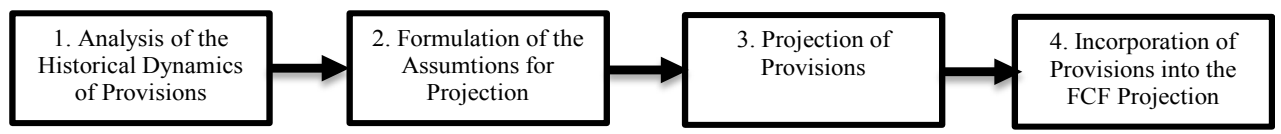

Figure 1. The algorithm of provisions projection for the purposes of DCF valuation

Source: own elaboration.

\section{Table 1}

Disclosure of the historical dynamics of provisions

\begin{tabular}{lllll} 
& Calculation & 2013 & 2014 & 2015 \\
\hline 1. Carrying amount of provisions at the end of the period & Exogenous & 130.0 & 140.0 & 150.0 \\
2. Additional provisions & Exogenous & 117.0 & 121.0 & 137.0 \\
3. Provisions used and reversed & $=4+2-1$ & 107.0 & 111.0 & 127.0 \\
4. Carrying amount of provisions at the beginning of the period & $=1-2+3$ & 120.0 & 130.0 & 140.0 \\
5. Used provisions & Exogenous & 40 & 50 & 80 \\
6. Unused provisions reversed during the period & $=3-5$ & 67 & 61 & 47 \\
7. Additional provisions as \% of sales & $=2 / 11$ & 0.96 & 1.04 & 1.04 \\
8. Provisions used and reversed as \% of sales & $=3 / 11$ & 0.88 & 0.95 & 0.97 \\
9. Used provisions as \% of provisions used and reversed & $=5 / 3$ & 37.38 & 45.05 & 62.99 \\
10. Reversed provisions as \% of provisions used and reversed & $=6 / 3$ & 62.62 & 54.95 & 37.01 \\
11. Sales & Exogenous & 12,125 & 11,660 & 13,155 \\
\hline
\end{tabular}

Source: own elaboration.

Table 1 presents a simplified disclosure format for reporting the historical changes in provisions consistent with the standard DCF valuation model. Variables taken from the financial statements of the company are marked as exogenous.

Next, in order to make a projection we make a simplifying assumption that the future dynamics of provisions is synchronized with that of the planned revenue, which means that 
additional, used and reversed provisions will be evolving in absolute values, but will remain constant as a percentage of the sales figure.

A similar assumption is adopted for the proportions of used and reversed provisions in the total amount of provisions which have been used and reversed. Such an assumption is not unrealistic and permits to prepare a reasonably accurate free cash flow projection. Drawing a clear distinction between the used and reversed provisions is necessary to highlight the influence of each of the elements on the free cash flow calculation, which will be clarified further. The appropriate order for planning the analysed variables is presented in Figure 2.

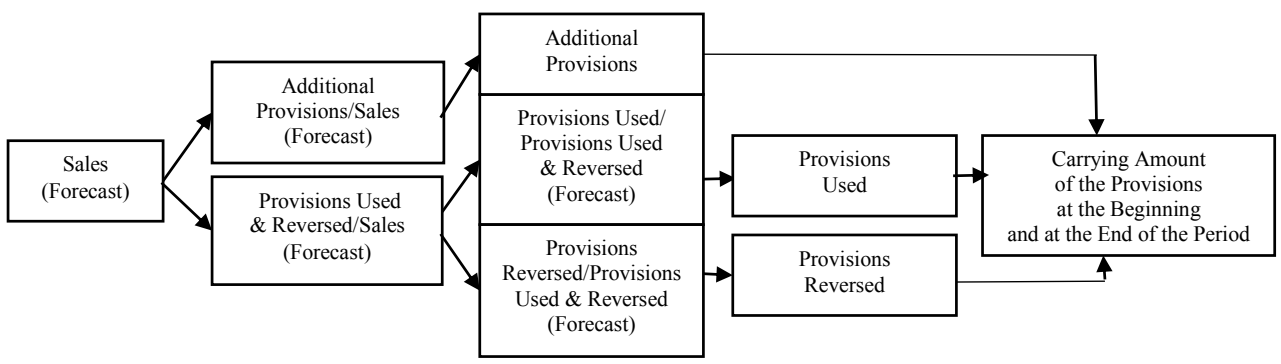

Figure 2. Planning order for preparation of the provisions projection

Source: own elaboration.

\section{Table 2}

Disclosure of the projected provisions

\begin{tabular}{|c|c|c|c|c|}
\hline & \\
\hline & Calculation & $2016 \mathrm{P}$ & $2017 \mathrm{P}$ & $2018 \mathrm{P}$ \\
\hline 1. Sales & Projected & 14,500 & 15,000 & 15,500 \\
\hline 2. Additional provisions as $\%$ of sales & A historical three-year average & 1.01 & 1.01 & 1.01 \\
\hline $\begin{array}{l}\text { 3. Provisions used and reversed as } \% \text { of sa- } \\
\text { les }\end{array}$ & A historical three-year average & 0.93 & 0.93 & 0.93 \\
\hline $\begin{array}{l}\text { 4. Used provisions as } \% \text { of provisions used } \\
\text { and reversed }\end{array}$ & A historical three-year average & 48.47 & 48.47 & 48.47 \\
\hline $\begin{array}{l}\text { 5. Reversed provisions as } \% \text { of provisions } \\
\text { used and reversed }\end{array}$ & A historical three-year average & 51.53 & 51.53 & 51.53 \\
\hline 6. Additional provisions & $=1 \times 2$ & 146,5 & 151,5 & 156,6 \\
\hline 7. Provisions used and reversed & $=1 \times 3$ & 134,9 & 139,5 & 144,2 \\
\hline 8. Used provisions & $=4 \times 7$ & 65,4 & 67,6 & 69,9 \\
\hline $\begin{array}{l}\text { 9. Unused provisions reversed during the } \\
\text { period }\end{array}$ & $=5 \times 7$ & 69,5 & 71,9 & 74,3 \\
\hline $\begin{array}{l}\text { 10. Carrying amount of provisions at the } \\
\text { beginning of the period }\end{array}$ & $\begin{array}{l}\text { Equal to the carrying amount at } \\
\text { the end of the previous period }\end{array}$ & 150,0 & 161,6 & 173,7 \\
\hline $\begin{array}{l}\text { 11. Carrying amount of provisions at the end } \\
\text { of the period }\end{array}$ & $=6-7+10$ & 161,6 & 173,7 & 186,1 \\
\hline
\end{tabular}

Source: own elaboration. 
After having performed the above calculations and basing them on the projected sales figure, we can estimate the predicted values for additional, used and reversed provisions (together and separately). The carrying amount of the provisions at the end of the reporting period will be transferred to the forecasted statement of the financial position, while the figures for new, used and reversed provisions will be used for the purposes of the projected free cash flow calculation. The format for projected provisions disclosure is presented in Table 2 .

\section{Projected Provisions and Free Cash Flow Calculation}

Depending on the nature of the provision, which is necessarily disclosed in the financial statement, the appropriate corrections are introduced to the free cash flow estimates as a result of creating new or reversing the previously recognized provisions. Usually, provisions are charged against revenue as an expense when used.

Table 3

Charging the changes in provisions against other operating income and other operating expenses

\begin{tabular}{|c|c|c|c|c|c|c|c|c|}
\hline & Calculation & 2013 & 2014 & 2015 & Calculation (projection) & $2016 \mathrm{P}$ & $2017 \mathrm{P}$ & $2018 \mathrm{P}$ \\
\hline $\begin{array}{l}\text { Other } \\
\text { operating } \\
\text { expense }\end{array}$ & $\begin{array}{l}=\text { Additional } \\
\text { provisions (Table 1, } \\
\text { position 2) }\end{array}$ & 1,170 & 121,0 & 137,0 & $\begin{array}{l}=\text { Additional provisions } \\
\text { (Table } 2 \text {, position } 6 \text { ) }\end{array}$ & 146,5 & 151,5 & 156,6 \\
\hline $\begin{array}{l}\text { Other } \\
\text { operating } \\
\text { income }\end{array}$ & $\begin{array}{l}\text { = Unused pro- } \\
\text { visions reversed } \\
\text { during the period } \\
(\text { Table } 1, \text { position } 6)\end{array}$ & 67,0 & 61,0 & 47,0 & $\begin{array}{l}=\text { Unused provisions re- } \\
\text { versed during the period } \\
\text { (Table } 2 \text {, position } 9 \text { ) }\end{array}$ & 69,5 & 71,9 & 74,3 \\
\hline
\end{tabular}

Source: own elaboration.

As demonstrated in Table 3, increase in provisions during the reporting period is recognized as part of other operating expenses, while reversed provisions are added to other operating income. This prompts the adjustments in the free cash flow calculations, which are made in accordance with the algorithm, which follows (exemplary changes are summarized in Table 4, changing lines are highlighted in bold type).

Used provisions cause the carrying amount of provisions at the end of the reporting period to decrease. In turn, this entails an increase in the working capital balance at the end of the period, or equivalently, an increase in working capital investment. The direct implication is a diminution of the free cash flow.

\section{Used provisions $\uparrow \Rightarrow$ Working capital $\uparrow \Rightarrow$ Working capital investment $\uparrow \Rightarrow \mathrm{FCF} \downarrow$}

Reversed provisions cause the carrying amount of provisions at the end of the reporting period to diminish, which causes the working capital balance to increase. In turn, investment in working capital increases. However, reversed provisions are recognized as part of 
other operating income, which after netting against other operating expenses (including the increase in provisions) increases the net operating profit after tax (NOPAT). As a result, the growth of investment in working capital is compensated by an increase in other operating income, causing the ultimate figure of free cash flow to remain unchanged.

Reversed provisions $\uparrow \Rightarrow$ Other operating income $\uparrow \cup$ Working capital $\uparrow \Rightarrow \Delta \mathrm{FCF}=0$

Table 4

Adjustments for provisions in the projection of free cash flow to firm

\begin{tabular}{|c|c|c|c|c|c|}
\hline \multicolumn{2}{|c|}{ FCFF } & \multirow{2}{*}{$\begin{array}{l}\text { Calculation / source of data } \\
\text { Table } 2 \text { position } 1\end{array}$} & \multirow{2}{*}{$\frac{2016 \mathrm{P}}{14,500}$} & \multirow{2}{*}{$\frac{2017 \mathrm{P}}{15,000}$} & \multirow{2}{*}{$\frac{2018 \mathrm{P}}{15,500}$} \\
\hline & Sales & & & & \\
\hline- & Operational costs & Company data (forecast) & 13,300 & 13,700 & 14,400 \\
\hline$=$ & EBITDA & & 1,200 & 1,300 & 1,100 \\
\hline- & Depreciation \& amortization & Company data (forecast) & 600 & 670 & 700 \\
\hline$=$ & EBIT & & 600 & 630 & 400 \\
\hline+ & Other operating income & Table 2 position 9 & 69,5 & 71,9 & 74,3 \\
\hline- & Other operating expenses & Table 2 position 6 & 146,5 & 151,5 & 156,6 \\
\hline- & Taxes & Market data & 114,0 & 119,7 & 76,0 \\
\hline$=$ & NOPAT & & 409,0 & 430.7 & 241,7 \\
\hline+ & Depreciation \& amortization & Company data & 600,0 & 670.0 & 700,0 \\
\hline- & Working capital investments & Company data & 100,0 & 110,0 & 200,0 \\
\hline$\overline{-}$ & $\begin{array}{l}\text { Increase in working capital investment } \\
\text { accounting for the used provisions }\end{array}$ & Table 2 position 8 & 65,4 & 67,6 & 69,9 \\
\hline- & Capital expenditure & Company data (forecast) & 800 & 700 & 600 \\
\hline+ & Residual value & & & & \\
\hline$=$ & FCFF + residual value & & 43,7 & 223,1 & 71,9 \\
\hline
\end{tabular}

Source: own elaboration.

\section{Actuarial Reserves in the DCF Valuation: Discount Rate and the Cost of Capital}

Pursuant to IAS 19 the cost of long-term post-employment benefit is determined based on a set of mutually compatible actuarial assumptions, which constitute the best estimates of the variables, which influence the ultimate amount of the liability appearing in the financial statement. The applied actuarial assumptions should be neither imprudent nor excessively conservative.

The actuarial assumptions include the following (IAS 19): demographic characteristics of the employees (mortality, employee turnover, use of the medical plans); financial assumptions (dynamics of salaries and benefits, expected rate of return on the assets contributed into a plan). 
One of the assumptions, which is particularly important for the correct evaluation of the entity's cost of capital, is the discount rate used to determine the present value of the postemployment and long-term obligations.

IAS 19 states that the discount rate used to determine the present value of the postemployment benefits, must be determined and based on the market yield on high quality corporate bonds at the end of the reporting period. In countries where the market for such securities is not characterized by sufficient depth, the market yield of the government bonds should be used as an appropriate benchmark. The currency and term of the bonds selected for benchmarking should match the currency and term of the valued post-employment benefit. In case of a lack of debt instruments with required maturity to match the timing of the valued obligation, the long-term discount rate is obtained by extrapolating the short-term yields along the yield curve (IAS 19).

What is even more important in case of long-term post-employment benefits is the interest cost, which is calculated as a product of the present value of the employer's obligation and the appropriate discount rate. The IAS 19 specifies that the calculated amount of the present value of the obligation will differ from the amount of liability recognized in the statement of financial position.

\section{Table 5}

Calculation of WACC and Equity Value Adjusted for the Actuarial Reserves

\begin{tabular}{|c|c|c|c|c|c|}
\hline WACC (basing on market values) & Calculation/source of data & $2015 \mathrm{E}$ & $2016 \mathrm{P}$ & $2017 \mathrm{P}$ & $2018 \mathrm{P}$ \\
\hline Actuarial reserves & Actuarial valuation & 500 & 500 & 500 & 500 \\
\hline 2. $\quad E /(E+D+R)$ & Company data (forecast) & $54.7 \%$ & $81.5 \%$ & $82.7 \%$ & $84.0 \%$ \\
\hline 3. $\mathrm{D} /(\mathrm{D}+\mathrm{E}+\mathrm{R})$ & Company data (forecast) & $40.4 \%$ & $16.2 \%$ & $15.0 \%$ & $13.8 \%$ \\
\hline 4. $\mathbf{R} /(\mathbf{D}+\mathbf{E}+\mathbf{R})$ & Company data (forecast) & $4.8 \%$ & $2.3 \%$ & $2.3 \%$ & $2.3 \%$ \\
\hline 5. Risk free rate & 10-year government bond yield & & $3.17 \%$ & $3.17 \%$ & $3.17 \%$ \\
\hline Tax rate & Market data & & $19.0 \%$ & $19.0 \%$ & $19.0 \%$ \\
\hline Market risk premium & Market data & & $5.2 \%$ & $5.2 \%$ & $5.2 \%$ \\
\hline Unlevered beta & Industry or company data & & 0.9 & 0.9 & 0.9 \\
\hline 9. Levered beta & Hamada equation (1972) & & 1.44 & 1.05 & 1.03 \\
\hline 10. Cost of equity capital & $=5+9 \times 7$ & & $10.6 \%$ & $8.6 \%$ & $8.5 \%$ \\
\hline 11. Cost of debt & Company data & & $5.5 \%$ & $5.5 \%$ & $5.5 \%$ \\
\hline 12. WACC & $=2 \times 10+3 \times(1-6) \times 11+4 \times 5$ & & $7.75 \%$ & $7.80 \%$ & $7.77 \%$ \\
\hline Enterprise value without cash & Sum of discounted FCFF & & & & \\
\hline$+\quad$ NOA \& Cash & Company data & & & & \\
\hline Enterprise value & & & & & \\
\hline Actuarial reserve & Actuarial valuation & 500 & & & \\
\hline - Interest bearing debt & Company data & & & & \\
\hline$=\quad$ Value of equity & & & & & \\
\hline
\end{tabular}


To put it simply, the actuarial reserves shall be treated as long-term interest-bearing debt, which entails some changes to the calculation of the weighted average cost of capital (WACC) and equity value of the company (since the value of actuarial reserves must be deducted from the enterprise value to arrive at the final equity valuation). Exemplary calculations of WACC and equity value are presented in Table 5. For simplicity of the presentation, we can assume that the actuarial reserves have been valued using the appropriate technique described above and remain constant throughout the projection period.

Taking into consideration that the Polish market for corporate bonds does not possess sufficient depth, the appropriate discount rate suggested for valuation of the actuarial reserves is the yield of the 10-year treasury bonds, which at the same time serves as a risk-free rate for the cost of equity calculation (performed in accordance with the standard CAPM model). The same interest rate will be used for the purposes of WACC calculation: since actuarial reserves are treated as part of debt obligations, it should be included into the cost of the capital calculation using the discount rate applied for reserves valuation as the interest cost, and share of reserves in the capital structure as the weighing coefficient. In order to calculate the value of equity, we deducted the amounts of interest bearing debt and actuarial reserves from the enterprise value.

\section{Conclusions}

The paper presents a detailed guide allowing one to incorporate the actuarial reserves and provisions into the valuation models. We recognize that uncertainty embedded in the estimates of the analysed variables may render the cash flow projection and cost of capital estimation particularly challenging. At the same time, the existing accounting standards combined with rigorous application of the logic of DCF models helps to address the technical intricacies of the treatment of provisions and actuarial reserves in the valuation process.

\section{References}

Damodaran A. (2010), Applied Corporate Finance, Wiley.

Hamada R.S. (1972), The Effect of the Firm's Capital Structure on the Systematic Risk of Common Stocks, “The Journal of Finance" t. 27, nr 2, pp. 435-452.

IASB (2011), International Accounting Standard 19 (Revised 2011).

IASB (2005), International Accounting Standard 37 (Revised 2005).

KSR 6 , Rezerwy, bierne rozliczenia międzyokresowe kosztów, zobowiazania warunkowe”. Załącznik do uchwały nr 7/08 Komitetu Standardów Rachunkowości z dnia 14 października 2008 r. 


\section{UJĘCIE REZERW ORAZ ZOBOWIĄZAŃ WARUNKOWYCH W WYCENIE DCF}

Streszczenie: W artykule przedstawiono praktyczne wskazówki do leczenia świadczeń pracowniczych, rezerw oraz zobowiązań warunkowych w modelach wyceny DCF. Rynki często napotykają na trudności podczas włączania w postaci rezerw aktuarialnych i rezerw, które same są wynikiem projekcji, do obliczania przepływów pieniężnych. Chociaż pojęcia świadczeń pracowniczych, rezerw i zobowiązań warunkowych są jasno określone w obu polskich i międzynarodowych standardach rachunkowości, zgodnie z ich logiką i założeń modelu DCF stwarza pewne problemy techniczne, które muszą stawić czoła w papierze. Między innymi, możemy odnosić się do kwestii związanych z rezerw aktuarialnych, które są często pomijane przy przedstawiający strukturę kapitału spółki i kalkulacji WACC. Proponujemy algorytm krok po kroku pozwalające przenieść wejść księgowych do modelu DCF, co może mieć istotne znaczenie dla praktykujących wycen.

Słowa kluczowe: rezerwy aktuarialne, rezerwy, zobowiązania warunkowe, wycena DCF

\section{Citation}

Mielcarz P., Osiichuk D., Wnuczak P. (2016), Actuarial Reserves, Provisions and Contingent Liabilities in DCF Valuation. Finanse, Rynki Finansowe, Ubezpieczenia, 1 (79), 289-298; www.wneiz.pl/frfu. 